\title{
The SDG-Check: Guiding Open Innovation towards Sustainable Development Goals
}

\author{
Justus von Geibler, Julius Piwowar, and Annika Greven
}

\author{
" There is nothing more frustrating than coming up with" \\ the right answer to the wrong question.
}

\author{
Tim Brown \\ CEO and President of IDEO \\ In Change by Design (2009)
}

\begin{abstract}
The "fuzzy front end" of innovation is argued to be crucial for the success and sustainability impact of a final product. Indeed, it is a promising area of focus in efforts to achieve the United Nations' 2015 Sustainable Development Goals (SDGs), which provide a globally accepted framework for sustainability. However, the usability of the 17 goals and the large number of sub-goals represent barriers to innovation practitioners. Moreover, this early innovation stage proves to be a challenge for corporate practitioners and innovators, largely due to the concept's intangible, qualitative nature and the lack of data. To help overcome these barriers, this article proposes a four-stage approach for structuring the innovation process using an online tool called the "SDG-Check", which help assess an innovator's sustainability orientation in the early phases of product and service development. It is a semi-quantitative tool to gather and combine assessments by experts involved in innovation processes with implications for the United Nations' SDGs. Furthermore, this article presents our first experiences in applying the SDG-Check based on three living lab innovation cases. The results indicate that the tools can support and inspire a dialogue with internal and external stakeholders with regards to sustainability considerations in the early design stages of product and service development.
\end{abstract}

\section{Introduction}

In the light of human impact reaching planetary boundaries (Rockström et al., 2009; Steffen et al., 2015) and various political sustainability objectives, such as the Sustainable Development Goals (SDGs) formulated by the United Nations (UN, 2015), various stakeholders have called for an accelerated transition towards sustainability (e.g., Jacob et al., 2016; Jha et al., 2016). Research and innovation are crucial to address this challenge and change production and consumption systems.

Fichter and Clausen (2016) define innovation as the process of developing and implementing a radically new or significantly improved solution. Following this understanding, radical innovations are a change of frame, which implies a discontinuity with the past. Indeed, radical innovations are characterized as disruptive, destroying, or breakthrough (i.e., "doing what we did not do before"). In contrast, incremental innovations are improvements within a given frame of solutions (i.e., "doing what we already did, but better" (Norman \& Verganti, 2014). In recent years, businesses have begun to open their innovation processes and engage societal actors (Howaldt \& Schwarz, 2012) to achieve both radical and incremental innovations. Stakeholders, including both other businesses as external partners and consumers, are increasingly included in the development of products and services, even at an early stage of innovation. The concept of open innovation refers to the utilization of inflowing and outflowing knowledge across company boundaries to accelerate internal innovation (Chesbrough, 2003).

In addition, sustainable innovations have started to emerge worldwide as consumers are increasingly demanding sustainable products (Oksanen \& Hautamäki, 2015). Although no universally accepted definition exists, sustainable innovations are usually associated with 


\section{The SDG-Check: Guiding Open Innovation towards Sustainable Development Goals} Justus von Geibler, Julius Piwowar, and Annika Greven

the support of sustainable development based on economically, socially, and environmentally sustainable principles. For example, Fichter (2005) defines a sustainable innovation as a "radically new or significantly improved technical, organizational, business-related, institutional or social solution that meets a triple bottom line of economic, environmental and social value creation. Sustainable innovation contributes to production and consumption patterns that secure human activity within the earth's carrying capacities".

The highest potential for shaping and designing innovations lies in the "fuzzy front end" of innovation, which is the very early stage of the innovation process. It begins when an opportunity is first considered worthy of further ideation, exploration, strategy formulation, and assessment, and it ends when a firm decides to invest in the idea, commit significant resources to its development, and launch the project (Dewulf, 2013). This applies especially to the sustainability potential of innovations (Hansen et al., 2009). Decisions made during this stage define a large share of the production costs and environmental impacts (Tischner, 2015). Furthermore, at this stage, decisions determine the path of the whole innovation process (Val-Jauregi \& Justel, 2007), such as decisions on either incremental improvements or radical/disruptive interventions (Norman \& Verganti, 2014).

However, implanting sustainability into innovation processes and assessing an innovation's sustainability impact are great challenges because of their complexity (e.g., Bonn \& Fisher, 2011; Lozano, 2015) and ambiguity (Engert et al., 2016). For example, the concept of sustainability dependents on a number of (conflicting) interests (e.g., social, ecological, and economical) and parameters that vary across industries, countries, and time (Salzmann et al., 2005). Presumed sustainable solutions can thus cause rebound effects due to unforeseen consequences indirectly in other areas (Buhl et al., 2017). Hence, there is a need to deal with complexity in sustainable innovation development and in early innovation stages. In order to exploit the sustainability potentials in innovation processes and to enable interim innovation assessments based on a systematic and strategic approach, it is necessary to define appropriate requirements and to build a common sustainability vision that can guide the innovation process and thus minimize or eliminate risks as well as detect opportunities for sustainable development (e.g., Broman \& Robert, 2017; Robert et al., 2013). Especially with an increasing radicalness of an innovation, the embeddedness of an innovation in individual, social, or cultural contexts of use is not ensured (Clausen et al., 2011). The SDGs could be the basis for the requirements that sustainable innovations face in order to achieve these ambitious goals. Furthermore, the approach of open innovation can significantly reduce the risk of innovations failing on the market, especially radical innovations in a difficult market or those facing technological uncertainties (Clausen et al., 2011).

Against this background, this article presents an approach to address sustainable development using a tool to assess sustainability orientation in the early stages of innovation based on the SDGs and stakeholder involvement. The concrete tool - the SDG-Check, which has been designed to identify and integrate relevant sustainability aspects in early stages of innovation processes was proposed by Echternacht and colleagues (2016).

This article is motivated by the very first experiences made with the SDG-Check in three living lab projects in the early stages of the innovation process. The main objective of this article is to discuss the SDG-Check as a tool for sustainability orientation and assessment based on the SDGs in the fuzzy front end of innovation and together with various stakeholders. The related research question is: How does the SDG-Check enable sustainability orientation and assessments in early innovation phases of innovation projects?

In the remainder of the article, the approach and research methodology are described, including the background on sustainability assessment in the front end of open innovation processes. Furthermore, well-known innovation models are compared to analyze the structure of innovation processes of the early stage in particular. In the results section, the SDG-Check and experiences from applying the SDG-Check as an online survey tool are presented and discussed in light of the need for robust and practical sustainability assessments in transformative research and innovation processes. The article ends with conclusions and suggestions for further research.

\section{Theoretical Approach}

Open innovation in the early stages of innovation Open innovation is especially relevant in developing product-service systems along with users and stakeholders (Liedtke et al., 2015). Involving stakeholder groups definitely requires interactive methods in interdisciplinary processes. Research on "co-creation" and a series of new business models and management tools, which include users in the innovation process, have lately been 


\section{The SDG-Check: Guiding Open Innovation towards Sustainable Development Goals Justus von Geibler, Julius Piwowar, and Annika Greven}

promoted by concepts of interactive innovation development, such as "open source innovation" (Muskat \& Sylvester, 2012), "wisdom of crowds" (Surowiecki, 2004), or the "lead user" concept (von Hippel, 1986), as well as "transformation and transition design" (Irwin, 2015; Schmidt-Bleek \& Tischner, 1995; Sommer \& Welzer, 2014). Several interactive methods were developed with stakeholders and users, for example, to involve non-users and lead users in innovation workshops for sustainable-living innovations (Diehl, 2011), or web 2.0 tools to use collective intelligence (Leimeister, 2010). Based on the Agile Manifesto (a method to develop software in small steps, with little planning and strong user integration), Cooper (2014) proposes to strengthen user integration.

The integration of perspectives from users and stakeholders also offers the opportunity to integrate sustainability aspects, especially if a wide range of different stakeholder perspectives are considered. However, the integration of stakeholders also has limitations with regard to the consideration of sustainability. The users might have a limited perspective, rooted in their experience of daily routines, which do not promote radical or disruptive innovation (Kuijer \& De Jong, 2011). Also, intense interactions with many stakeholders are time and resource-intensive, which hinders the innovation process. Furthermore, companies can be unwilling to receive and share knowledge and intellectual property (Søndergaard \& Burcharth, 2011).

To enable more systemic innovation, it is important to identify and integrate relevant sustainability aspects as early as possible, given that product and service design at this stage are still adaptable and early-stage modifica-

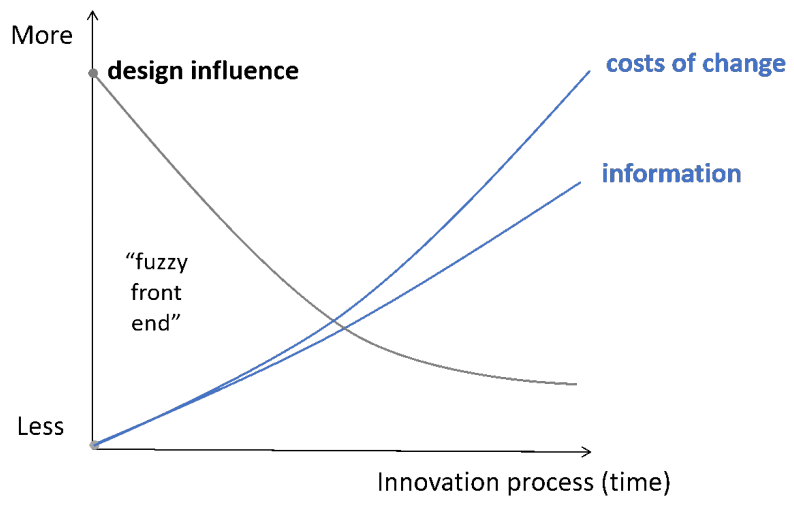

tions are relatively low-cost compared to later modifications (see Figure 1). At the beginning of the process, the degree of freedom and influence on the project outcome is high, whereas little information is available and the cost of change is low. At later stages in the process, the availability of information is higher, but then the cost of change has increased (Verworn 2009). The challenge in the front end is created by the low amount and quality of information and certainty.

\section{Structuring the innovation process}

The multitude of models of innovation processes in the literature shows that there is not a single model that is transferable to all fields of application (Verworn \& Herstatt, 2000). Innovation processes can be structured in different iterative phases, for example, from three to five or even nine phases (Geibler et al., 2016). However, in practice, it is difficult to comply with such models as they idealize and standardize the time flow of innovation processes.

The sustainability requirements could inform, for example, the design brief, which provides the foundation to the entire innovation and design process and can be seen as the report or summary of the investigation steps and the decisions taken in the front end, as shown in Figure 2 (Dewulf, 2013). It is a written description of a project - an agreement between the parties involved and a roadmap defining the various steps that will be followed (Phillips, 2004).

However, referring to Dewulf's (2013) stages of a design brief in the front end, it is not clear when an innovation is still considered as an early stage innovation and how this is connected to further innovation development,

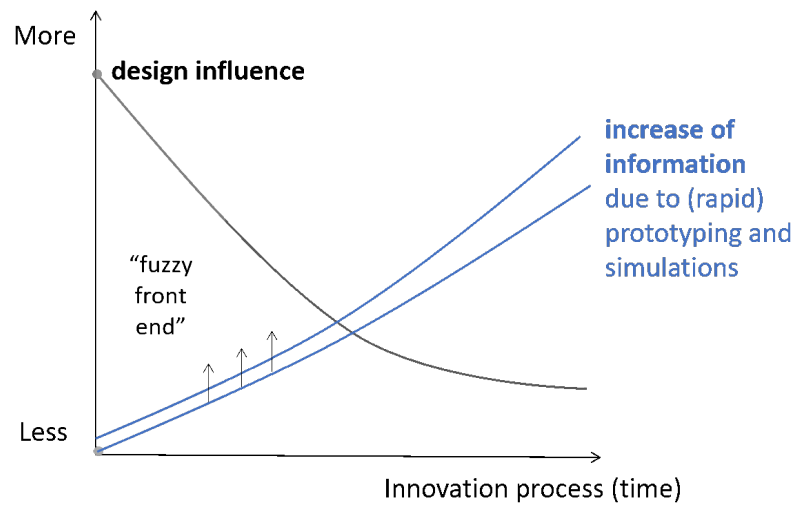

Figure 1. Evolution of influence, costs of changes, and information during the innovation process (left) and opportunities based on prototyping (right)

(Source: own illustration based on Ullman, 1997 and von Hippel, 1993, and modified by Herstatt \& Verworn, 2001) 


\section{The SDG-Check: Guiding Open Innovation towards Sustainable Development Goals Justus von Geibler, Julius Piwowar, and Annika Greven}

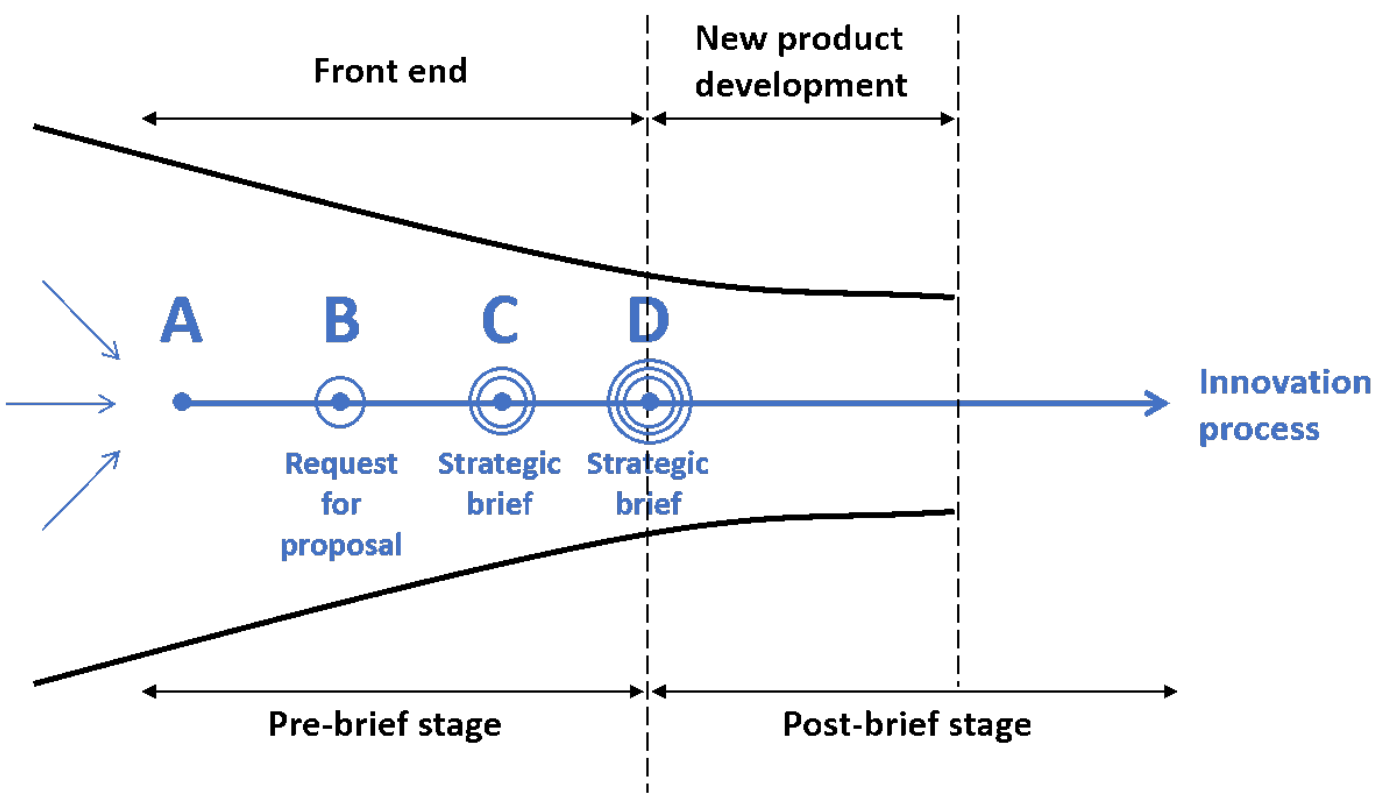

Figure 2. The various stages of a design brief in the front end of the innovation process (Source: Based on Dewulf, 2013)

that is why two internationally known models from the literature have been chosen and linked to each other to further analyze the temporal structuring of early innovation processes. The commonly used Stage-Gate process, originally described by Cooper (1990), has been chosen as the conceptual frame of the SDG-Check based on the evaluation of the experiences and discussions with relevant stakeholders. This model consists of several work phases, which are connected with each other via decision points at which the further implementation of the innovation process is determined. Due to the defined decision points, the Stage-Gate model (Cooper, 1990, 2001) presents a good starting point for the development of a structured approach for the integration of sustainability assessment in early innovation. In addition, the Innovation Readiness Levels (IRL) model (Geibler et al., 2016) is used to assess the maturity of innovations. The IRL model is derived from the Technology Readiness Levels (TRL) model (Mankins, 1995, 2009), which is a framework that has been used in many variations across industries to provide a measurement of technology maturity from idea generation to commercialization and understanding of required capabilities and resources. As the innovation process is not only limited to technological development but should also include the interaction of users or stakeholders for example, the TRL model has been extended to innovation readiness levels. With its nine levels, the IRL model presents a rather detailed approach to assess the maturity of innovation, whereas the Stage-Gate model describes the innovation process in a broader manner. Both models will be linked and used as a foundation to address the front end of innovation.

The four phases of the Stage-Gate model are: 1) the preliminary investigation, 2) the detailed preliminary investigation, 3) prototype development, and 4) the field test (Liedtke et al., 2015). In the case of an "ideal" procedure, the process can be structured and sectioned by five different points of decision-making (so-called "gates") (see Figure 3). According to Grönlund and colleagues (2010), the front end of innovation is defined as a phase where opportunities are discovered and ideas are generated, as opposed to later stages, which concentrate on a concrete concept development, testing, and commercialization. This can be linked to the preliminary investigation phase including the two decision points "project estimation" and "project decision", which are concerned with the conceptual definition of the innovation in terms of function and field of application (see Figure 4). The evaluation of those two gates particularly intends to ensure the general orientation of the innovation towards sustainability goals and the identification of sustainability effects (Echternacht et al., 2016).

The IRL model (Geibler et al., 2016), derived from the TRL model by Mankins (2009), divides the innovation process into nine individual and distinct innovation readiness levels (Geibler et al., 2016; see Figure 5). The 


\section{The SDG-Check: Guiding Open Innovation towards Sustainable Development Goals} Justus von Geibler, Julius Piwowar, and Annika Greven

Idealized time flow of an innovation process

\begin{tabular}{|c|c|c|c|c|c|}
\hline $\begin{array}{l}\text { Extension of } \\
\text { Thom's phase } \\
\text { model (by } \\
\text { Trommsdorff ) }\end{array}$ & $\begin{array}{l}\text { Idea Generation } \\
\text { Situation } \\
\text { Analysis } \\
\text { Idea Creation }\end{array}$ & \multicolumn{2}{|c|}{$\begin{array}{l}\text { Acceptance and first } \\
\text { Realisation of ideas iterative } \\
\text { - Idea Evaluation and } \\
\text { Selection } \\
\text { - Strategy Development }\end{array}$} & $\begin{array}{l}\text { Realization of Ideas } \\
\text { - Developers with } \\
\text { permanent test phase for } \\
\text { market and product } \\
\text { - Product Launch }\end{array}$ & $\begin{array}{l}\text { Product } \\
\text { Launch }\end{array}$ \\
\hline $\begin{array}{l}\text { Front End of New } \\
\text { Product } \\
\text { Development } \\
\text { (Dewulf) }\end{array}$ & $\begin{array}{l}\text { Front End } \\
\text { - Request for } \\
\text { Proposal } \\
\text { - Strategic Brief } \\
\text { Design Brief }\end{array}$ & \multicolumn{2}{|c|}{ New Product Development } & \multicolumn{2}{|l|}{ Innovation Process } \\
\hline $\begin{array}{l}\text { Stage-Gate } \\
\text { (Model by Cooper) }\end{array}$ & $\begin{array}{l}\text { Preliminary } \\
\text { Investigation }\end{array}$ & $\begin{array}{l}\text { Investigation, } \\
\text { Business plan }\end{array}$ & $\begin{array}{l}\text { Develop- } \\
\text { ment and } \\
\text { Prototype }\end{array}$ & Testing and Validation & $\begin{array}{c}\text { Product and } \\
\text { Market } \\
\text { Launch }\end{array}$ \\
\hline $\begin{array}{l}\text { Technology } \\
\text { Readiness Levels } \\
\text { (TRL) (Model by } \\
\text { Mankins) }\end{array}$ & TRL 1 , TRL 2 & \multicolumn{2}{|c|}{ TRL 3, TRL 4} & TRL 5, TRL6, TRL7 & TRL 8, TRL 9 \\
\hline
\end{tabular}

Figure 3. A comparison of the phases of innovation models (Source: own illustration based on Geibler et al., 2016)

TRL model is used internationally for sustainable innovation processes (Nakamuraet et al., 2013), and it provides a common understanding of the maturity of an innovation (Geibler et al., 2016). The levels can be connected with the points of decision-making in the Stage-Gate model, or rather the first two gates that have already been linked to the early stage of an innovation. In the first decision gate "project estimation", an overall estimation is conducted to identify existing needs or expectations of users and the users are observed to gather relevant data (Geibler et al., 2016). This conforms to the first innovation readiness level, as it consists of observing and reporting basic principles regarding the innovation. In the "project decision" gate, these data serve as a foundation to determine whether a new product or system solution will be developed. If it is decided to proceed with the project, the need that the innovation addresses is defined. This step aligns with IRL 2, as a broad idea of an innovation or application concept is formulated (Geibler et al., 2016).
As data availability and resources for assessment are limited in the early stages of an innovation, related sustainability assessments tend to be rather simple and only supportive for awareness raising, general orientation, and the broad identification of sustainability effects. Consequently, checklists can be used as an assessment instrument. For example, regarding the first gate, "project estimation", it can be asked to what extent the innovation can contribute to one of the UN's 17 SDGs. A minimum number of criteria should be defined in order to satisfy the sustainability assessment positively, for example, that at least three SDGs are positively influenced. At the second gate, "project decision", these can be substantiated by using the sub-goals. In principle, this ensures an improved assessment of the potential to contribute to a sustainable development. With the help of such an instrument, the developer becomes aware of the goals that can and should give direction to the innovation process. In addition, at this point the estimation of potential can also 


\section{The SDG-Check: Guiding Open Innovation towards Sustainable Development Goals Justus von Geibler, Julius Piwowar, and Annika Greven}

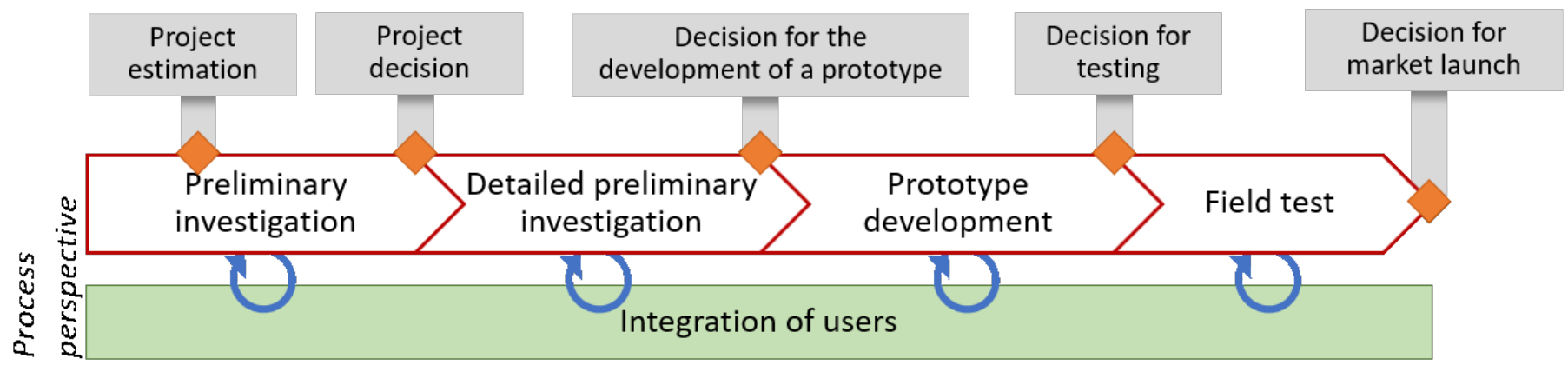

Specification of the system and The reference system

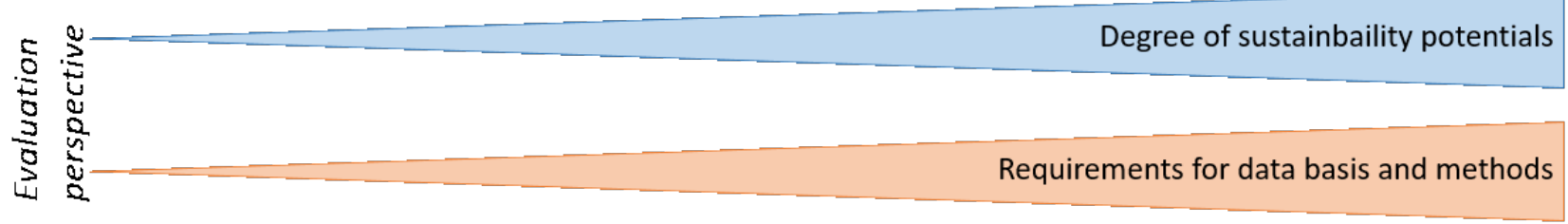

$\because \quad$ Checklists and tools for orientation and inspiration e.g. SDG-Check, 10 Golden Rules, Biomimicry 3.8
Tools for concrete measurements e.g. MIPS, Hotspots Analysis

Point of decision

Phase

Figure 4. Phases and gates in the innovation processes and evaluation (Source: translated from Geibler et al., 2016)

serve the developers as inspiration for the description of the target market and the target group of the innovation.

Furthermore, assessing the sustainability within innovation processes requires defining and describing both the innovation system and the reference system. In addition, stakeholders' needs and objectives must be defined for this analysis, for example, based on a guiding vision (IISD, 1997):

1. Describing the innovation system allows identifying and evaluating the innovation's sustainability in terms of its techno-physical, usage system, and cultural levels (see Figure 6; Paech, 2005). The techno-physical level describes the direct effect of the innovation's production or development, including direct effects upstream, for example, the technical eco-efficiency improvements of a car. The usage system describes direct and indirect effects of the innovation and during the usage phase, such as the efficiency in use gained by product-service systems such as car-sharing models (Buhl et al., 2017). The cultural level describes the innovation's cultural effect. For example, questioning the need for mobility and thus substituting the underlying "want" with a different solution, such as satisfying the want for recreation not with faraway holiday destinations but with near-by holiday destinations and thus forgoing (most of the) mobility services. Innovations, which are highly culturally effective, have more impact potential (for cultural-institutional change) than innovations, which only have technical effects (for technical change). This means, for example, that eco-efficiency gains can be achieved with relatively little effort in the new product development stage of an innovation process. However, to tackle root problems at higher system and cultural levels, the problem needs to be already integrated in the front end of the innovation process. After this crucial phase only technical eco-efficiency improvements or product redesign are possible (Dewulf, 2013), not radical/disruptive changes (Norman \& Verganti, 2014).

2. Further, comparing the innovation system and the reference system (e.g., available products or other innovative concepts) allows estimations of the potential 


\title{
The SDG-Check: Guiding Open Innovation towards Sustainable Development Goals
} Justus von Geibler, Julius Piwowar, and Annika Greven

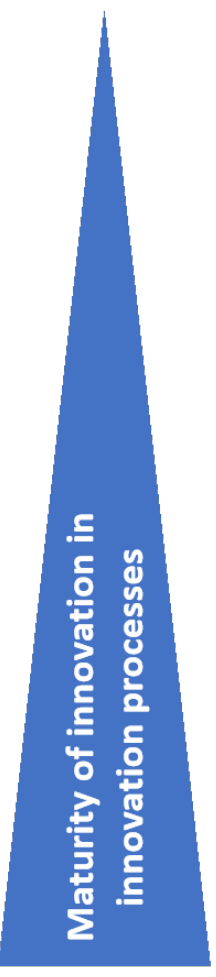

\author{
IRL 1 - Basic principles observed and reported \\ IRL 2 - Technology concept and/or application formulated
}

Phase 1:

Preliminary Investigation

IRL 3 - Analytical and experimental critical function and/or characteristic proof-of-concept

Phase 2:

Detailed Preliminary

IRL 4 - Component and/or breadboard validation in laboratory environment

Investigation

IRL 5 - Component and/or breadboard validation in relevant environment

IRL 6 - System/subsystem model or prototype demonstration in a relevant environment

Phase 3:

Prototype Development

IRL 7 - System prototype demonstration in the planned operational environment

IRL 8 - Actual system completed and "qualified" through test and demonstration

Phase 4:

IRL 9 - Actual system "proven" through successful system and/or mission operations

Field test

Figure 5. Innovation Readiness Levels in a Living Lab (Source: own illustration derived from Mankins, 2009)

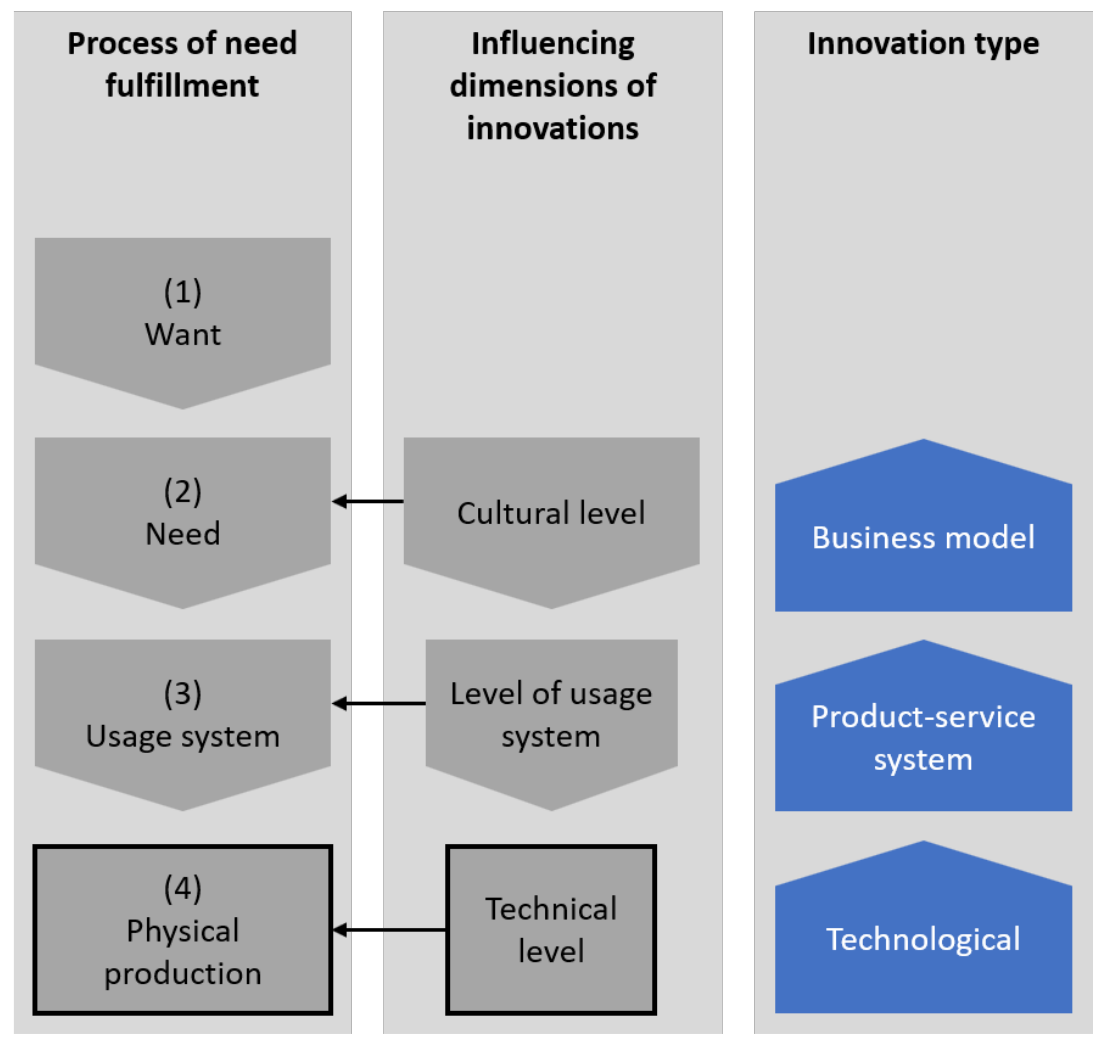

Figure 6. Three levels of the innovation system (Source: Hansen, 2009, based on Paech, 2005) 


\section{The SDG-Check: Guiding Open Innovation towards Sustainable Development Goals} Justus von Geibler, Julius Piwowar, and Annika Greven

for change towards sustainability. If the innovation is already positioned on the market, sustainability and change "effects" can be assessed and analyzed (Hansen et al., 2009).

3. Assessing sustainability within innovation processes, stakeholders' needs and objectives must be defined. In this process, both stakeholder groups should be included: actively involved groups (e.g., employees and users with individual interests such as well-being and satisfaction) as well as passively involved or "affected" groups (e.g., administrative stakeholders or future generations with collective interests such as ecological concerns).

This assessment allows insight and inspiration about stakeholders' needs and desires to be gained from many different and even conflicting viewpoints and opinions, for example those sought from brand promise, technology, societal, and ecological trends as well as mere vision of renewal.

In order to manage this complexity in the front end of innovation, Val-Jauregi and Justel (2007) suggest different tools, methods, and techniques, such as creativity techniques, scenarios, technology scouting, and market and opportunity analyses. Furthermore, there are specific methods and tools that enable exploring individual stakeholder concerns in the early stage of an innovation. Diefenbach and Hassenzahl (2017) have chosen seven psychological needs as the starting point for the innovation process, for example as facilitated by Need Cards (Hassenzahl et al., 2013). Similarly, van Dijk and Hekkert (2014) introduced the Vision in Product Design (ViP) method that primarily explores the meaning of a product or service in relation to a future context. Thereby, these methods allow innovators to, for example, question and rethink the traditional business models and break with traditional innovation routines. In addition, there are methods and tools that specifically focus on sustainability in the early stage of an innovation, such as Biomimicry 3.8 (Baumeister et al., 2013) or the 10 Golden Rules (Luttropp \& Lagerstedt, 2006). Both of these examples serve as guiding tools towards sustainable product design. Geibler and colleagues (2016) suggest an SDG-Check for the assessment of sustainability potentials, referring to the SDGs. The SDGs are broadly defined and extend from fighting poverty to improving education and health to mitigating climate change as well as protecting the oceans and ecosystems. Under the title "Transforming Our World: The 2030 Agenda for Sustainable Development", the UN member states created a catalogue of 17 goals and 169 subordinate goals; the real- ization of these goals by 2030 is voluntary, but for the first time it is universally valid, equally for developing, emerging, and industrialized countries (UN, 2015).

\section{Research Methodology}

The research process involved three main phases:

1. Development of the SDG-Check as an online tool

2. Application of the SDG-Check in three cases

3. Evaluation of the SDG-Check application

Phase 1: Development of the "SDG-Check" as an online tool The SDG-Check was initiated in the living lab research project INNOLAB (2018) and was based on a literature review focusing on conceptual and methodological understanding of sustainability assessments within open innovation processes (Echternacht et al., 2016). Questions and answer options were integrated in an online survey tool. In the results section of this article, the development of the SDG-Check is described, focusing on the functional requirements and the concrete steps.

\section{Phase 2: Application of the SDG-Check in three cases}

The SDG-Check was applied in three innovation projects within three German living labs (2016-2017) (see Table 1). The objective of the innovation projects was to co-create and test (digital) assistance systems, which encourage sustainable consumption in the fields of living, retail, and mobility. The innovation process was facilitated and guided by different living lab methods including the SDG-Check. The SDG-Check was applied by three to seven project members in each project involving practitioners from small and medium-sized enterprises (SMEs) and researchers. This enabled researchers to compare, for example, different perspectives on sustainability within each team. Furthermore, the SDG-Check was applied as early as possible in the project (in the concept phase) as well as at a later stage (in the prototype phase). This enabled researchers to compare results based on different temporal stages, for example (see Kahl et al., 2017; Krein et al., 2017; Meurer et al., 2017).

\section{Phase 3: Evaluation of the SDG-Check application}

After the application of the SDG-Check, and together with the innovation project members, the effectiveness and efficiency of the SDG-Check was evaluated. This analysis is based on a written survey with the three project leads and a discussion in a workshop within the project teams (13 participants). 


\section{The SDG-Check: Guiding Open Innovation towards Sustainable Development Goals} Justus von Geibler, Julius Piwowar, and Annika Greven

Table 1. Overview of the three innovation projects and the application of the SDG-Check

\begin{tabular}{|l|l|l|l|}
\hline Project Name & Innovation Objective & SDG-Check Participants & SDG-Check Application Phase \\
\hline Living & $\begin{array}{l}\text { An assistant system encourages sustainable } \\
\text { ventilation behaviour to reduce energy } \\
\text { consumption and to avoid mould in private } \\
\text { households. }\end{array}$ & $\begin{array}{l}\text { 5 participants involving } \\
\text { practitioners from SMEs } \\
\text { and researchers }\end{array}$ & Concept phase (2016) \\
\hline Retail & $\begin{array}{l}\text { An assistant system encourages sustainable } \\
\text { shopping behaviour in a supermarket } \\
\text { (point of sale). }\end{array}$ & $\begin{array}{l}\text { 7 participants involving } \\
\text { practitioners from SMEs } \\
\text { and researchers }\end{array}$ & Protonase (2017) \\
\hline Mobility & $\begin{array}{l}\text { An assistant system encourages sustainable } \\
\text { mobility behaviour for the elderly. }\end{array}$ & $\begin{array}{l}\text { 3 participants involving } \\
\text { practitioners from SMEs } \\
\text { and researchers }\end{array}$ & \\
\hline
\end{tabular}

The survey was carried out in German amongst the innovation managers of three living lab projects in Germany. The questionnaire objective was to gather practical insights and experience on the application of different methods and tools (including the SDGCheck). The aim was to understand their impact on success as well as future potentials and limitations. The questionnaire included both closed-ended and openended questions (Table 2).
At the end of the innovation project, the three project teams (including practioners) discussed the experiences with the living lab methods including the SDG-Check during a workshop. The guiding questions of the workshop included: What are the results of the SDG-Check? How do you evaluate the relevance of the method after the application? What can be improved? The results of the workshop were summarized in the project reports (see Kahl et al., 2017; Krein et al., 2017; Meurer et al., 2017).

Table 2. Questionnaire framework for the SDG-Check evaluation (Source: Geibler et al., 2018).

\begin{tabular}{|c|c|c|c|}
\hline \multicolumn{2}{|c|}{ Questionnaire Type and Focus } & Guiding Question & Five-Scale Ranking \\
\hline \multirow{4}{*}{$\begin{array}{l}\text { Closed-ended questions } \\
\text { focusing on methods } \\
\text { effectiveness }\end{array}$} & User integration & \multirow{4}{*}{$\begin{array}{l}\text { How relevant are the methods you } \\
\text { use to improve the chances of } \\
\text { exploitation and sustainability } \\
\text { orientation? } \\
\text { Please score the methods } \\
\text { according to the given criteria. }\end{array}$} & \multirow{8}{*}{$\begin{array}{l}\text { (--) very insufficient } \\
\text { (-) insufficient } \\
(0) \text { neutral } \\
\text { (+) good } \\
\text { (++) very good } \\
\text { (n.a.) not applicable; no or } \\
\text { insufficient data available }\end{array}$} \\
\hline & User context integration & & \\
\hline & Social aspects & & \\
\hline & Ecological aspects & & \\
\hline \multirow{4}{*}{$\begin{array}{l}\text { Closed-ended questions } \\
\text { focusing on methods } \\
\text { efficiency }\end{array}$} & Cost efficiency & \multirow{4}{*}{$\begin{array}{l}\text { How user-friendly and efficient } \\
\text { are the methods? } \\
\text { Please score the methods } \\
\text { according to the given criteria. }\end{array}$} & \\
\hline & Technical efficiency & & \\
\hline & Time efficiency & & \\
\hline & Usability & & \\
\hline \multirow{2}{*}{ Open-ended questions } & Advantages & \multirow{2}{*}{\multicolumn{2}{|c|}{$\begin{array}{l}\text { What were main advantages, limitations, and challenges of the method } \\
\text { during your application? }\end{array}$}} \\
\hline & Limitations and challenges & & \\
\hline
\end{tabular}




\section{The SDG-Check: Guiding Open Innovation towards Sustainable Development Goals} Justus von Geibler, Julius Piwowar, and Annika Greven

\section{Results and Discussion}

\section{Description and development of the online tool "SDG-Check"}

The SDG-Check focuses on potential effects an innovation could have regarding the 17 goals and their subgoals. The SDG-Check is designed to raise consciousness about these goals and their thematic diversity, so that the stakeholders are more attentive to options to integrate these goals in business modelling, for example. The tool development (Echternacht et al., 2016) was framed by the following requirements:

- The tool's objective is to identify potential sustainability effects (risks and opportunities) of an innovation within (early-stage) development processes. Furthermore, the tool should enable orientation and a common understanding of sustainability goals and to inspire ideation processes as well as business models. This means that the tool will not be able to measure specific sustainability aspects, such as carbon dioxide emissions.

- The tool's target group is members of multidisciplinary innovation teams, such as engineers, designers, and sustainability and non-sustainability experts. The results of the tool are based on self-assessment by individuals or groups.

- The usability criteria (ISO 9241-210, 2010) for the tool are the following: results of the SDG-Check should be transparent and comparable, for example, with assessments of users or with later assessments; the application should be intuitive and understandable; sustainability knowledge should not be required; and the time needed for the individual tool application should be less than 20 minutes.

As a result of these requirements, the SDG-Check tool is built on an online checklist and a stepwise approach with two levels of detail focusing on the 17 SDGs (level 1) and their sub-goals (level 2). The goals are evaluated based on a seven-step scale ranging from -3 (severe risk) to +3 (high opportunity).

Step 1 (level 1) of the SDG-Check serves to estimate whether the innovation creates opportunities or risks concerning the 17 SDGs. To do this, it is estimated whether the innovations have positive or negative potential with regard to the 17 SDGs using a seven-step scale. The SDG-Check's first step is shown in Figure 7.
Step 2 (level 2) of the SDG-Check can be applied during the innovation process. Here, the focus is on the subgoals of the SDGs and, for usability reasons, only for a selected number of SDGs. The selection covers the six main goals of Step 1 that were evaluated with the highest values related to opportunities (3 goals) and risks ( 3 goals). The participants evaluate the sub-goals in terms of opportunities and risks also using the sevenstep scale (ranging from -3 to +3 ). For the aggregation of the single assessments at goal level the Chance-RiskValue (CR-Value) is used as a means of the single assessment values at sub-goal level. As an example, Figure 8, illustrates Step 2 with sub-goal questions of the SDG 12 (Responsible consumption and production). The questions for the other sub-goals can be found in Echternacht and colleagues (2016).

\section{Results of the SDG-Check}

The SDG-Check results were assessed in three innovation projects for both Steps 1 and 2. For each project, the results are based on the self-assessments by the participants and calculated as CR-Values as well as value ranges. This method enabled an illustrative SDG ranking, which was presented to the participants for further discussion. As an example, Figure 9 and Figure 10 illustrate results of the SDG-Check from the innovation project "Retail" involving assessments of seven project members.

The results illustrate that the most significant opportunities and risks can be easily identified. In the case of the innovation project "Retail" (see Figure 9), the most significant opportunities of the evaluated shopping assistance system are linked to the goals "Responsible production and consumption", "Life below water", "Industry and innovation and infrastructure", and "Good health and wellbeing". The results of Step 2 present the views of the participants concerning the relevance of related sub-goals of the SDGs. For example, as Figure 10 shows, the innovation can contribute to SDG 12's subgoals "Efficient usage of natural resources" and "Restoring sustainable resource management and protection of marine and costal ecosystems" (Kahl et al., 2017). Sub-goals also can be identified as minor risks, which means that the innovation could affect them negatively. In the innovation project "Retail", this included, for example, "Increasing the wealth of the poorest $40 \%$ of the population" and "Raising exports to developing countries". The figures also highlight those goals or subgoals for which the team has divergent viewpoints. 


\section{The SDG-Check: Guiding Open Innovation towards Sustainable Development Goals Justus von Geibler, Julius Piwowar, and Annika Greven}

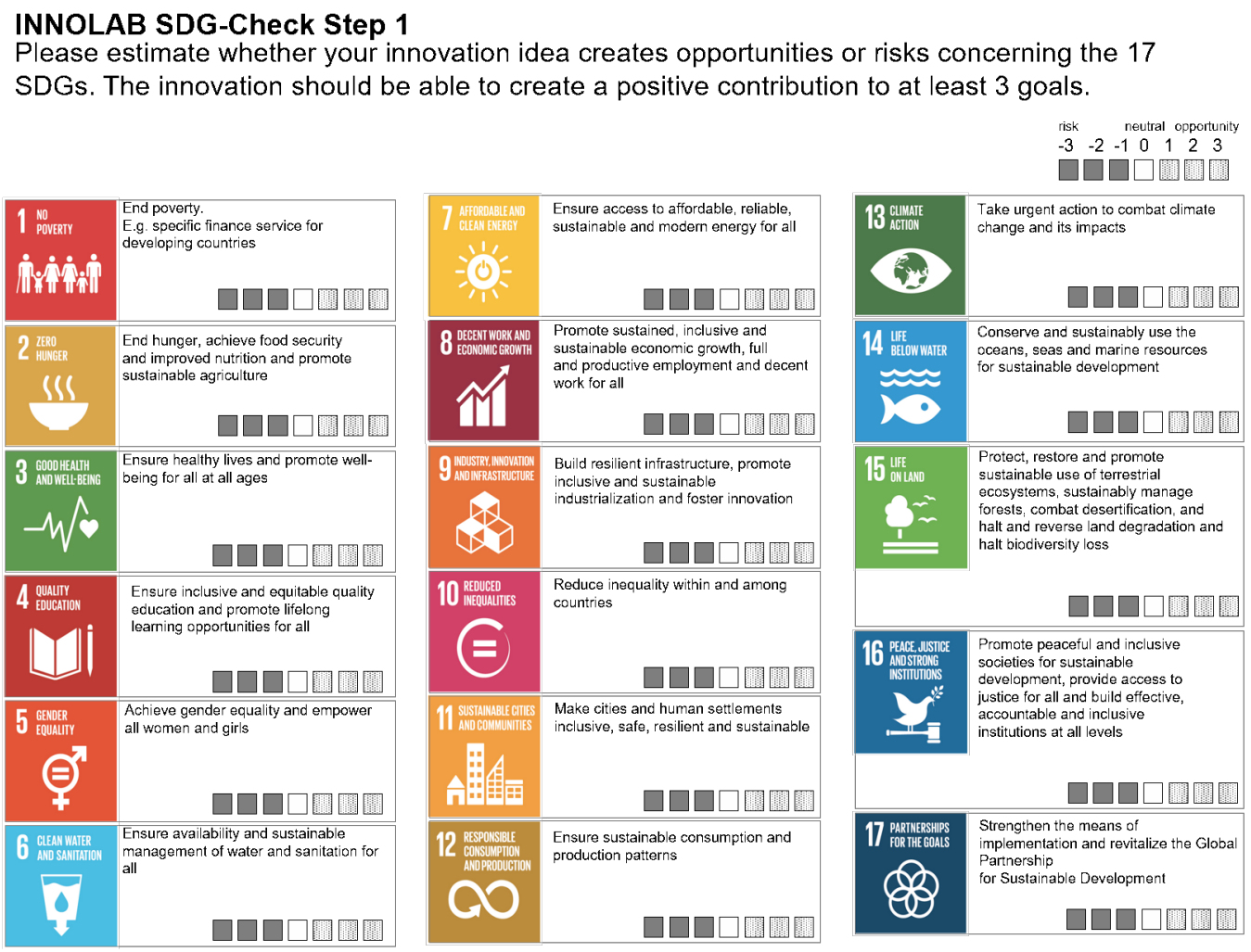

Figure 7. Step 1 of the SDG-Check (Source: Geibler et al., 2016; specification of the SDGs based on UN, 2015).

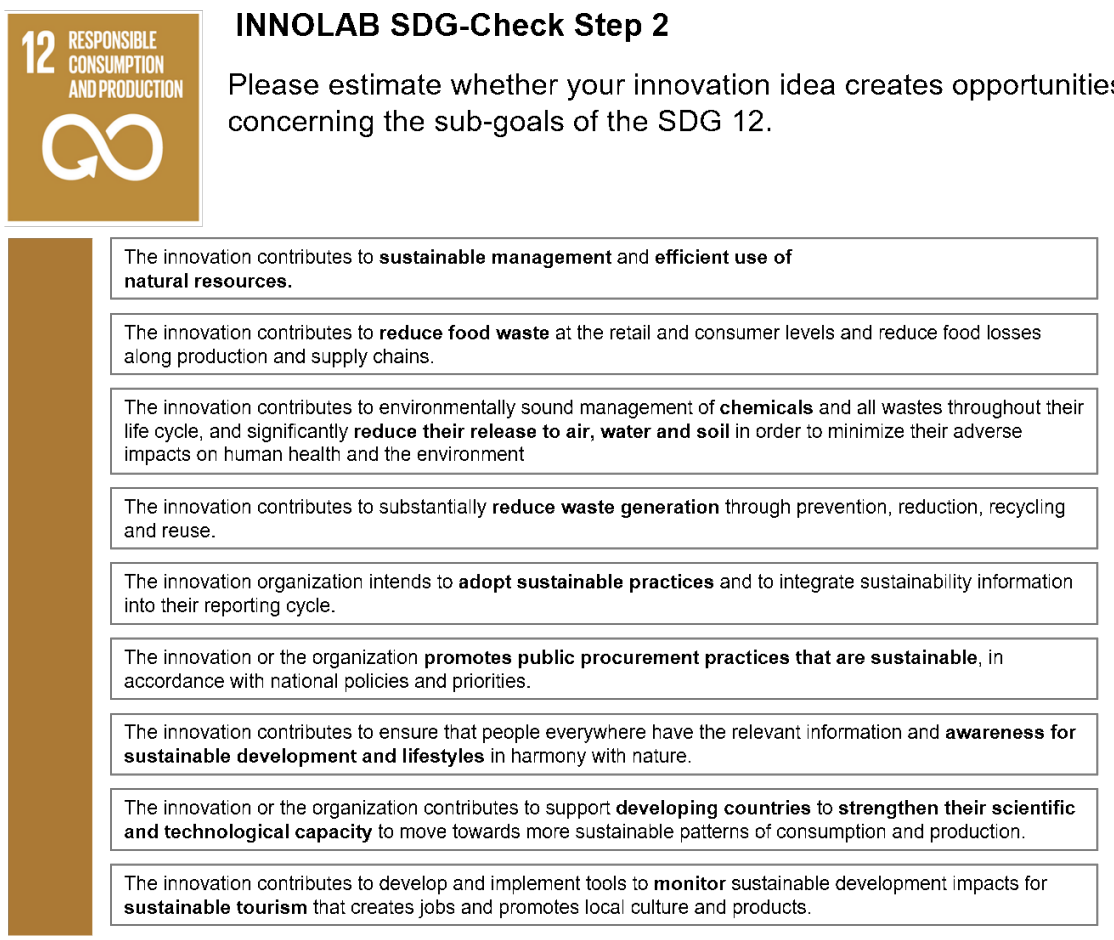

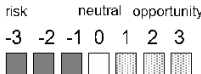

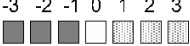

$\square \square \square \square$ 圆圈圈

$\square \square \square \square$ 圈圆

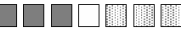

$\square \square \square \square$ 圆國

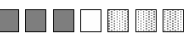

$\square \square \square \square$ 國圆

$\square \square \square \square \square \square$

口口圈圆圆

Figure 8. Step 2 of the SDG-Check, taking the example of SDG 12 "Responsible production and consumption" (Source: Based on Geibler et al., 2016; specification of the SDGs based on UN, 2015) 


\section{The SDG-Check: Guiding Open Innovation towards Sustainable Development Goals Justus von Geibler, Julius Piwowar, and Annika Greven}

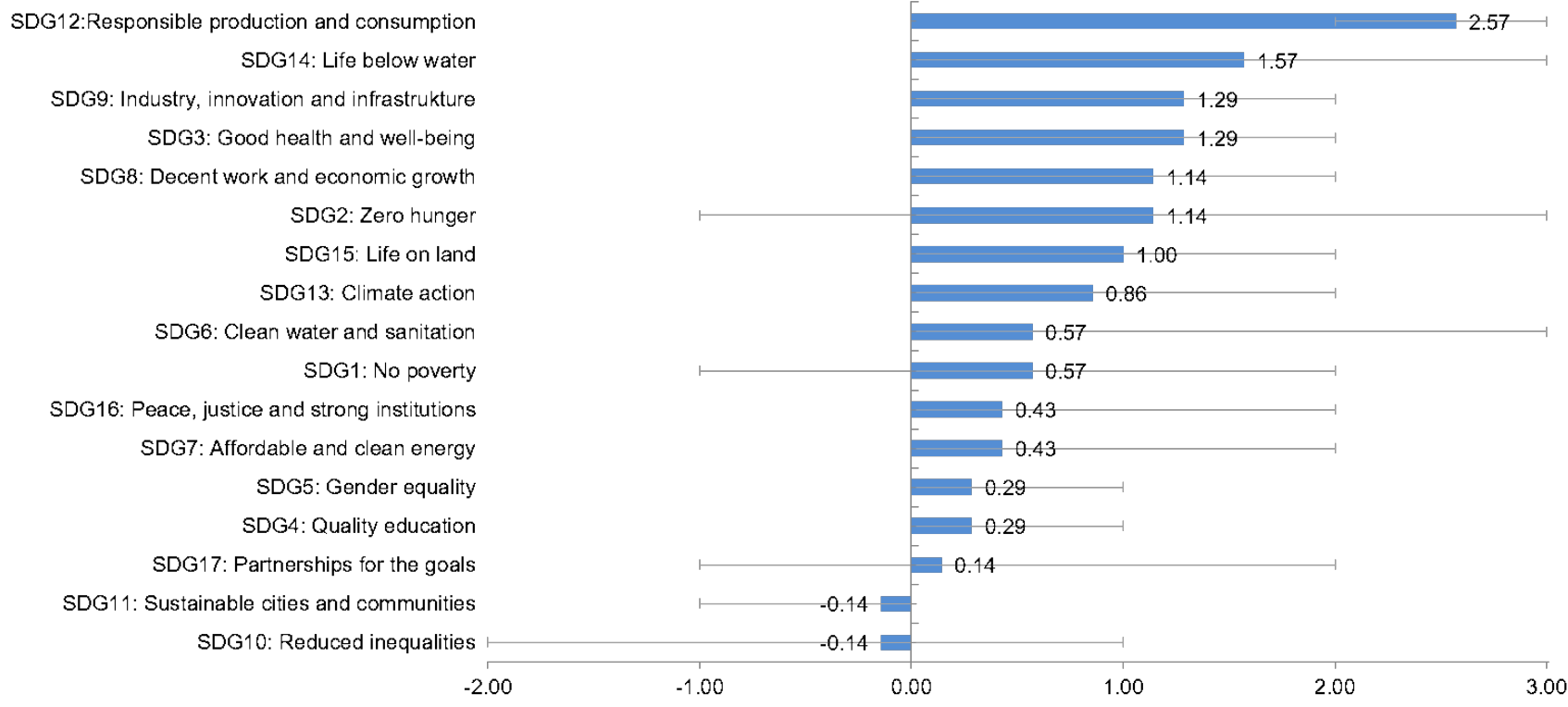

Figure 9. Results of the SDG-Check (Step 1) in the innovation project “Retail” (Source: translated from Kahl et al., 2017)

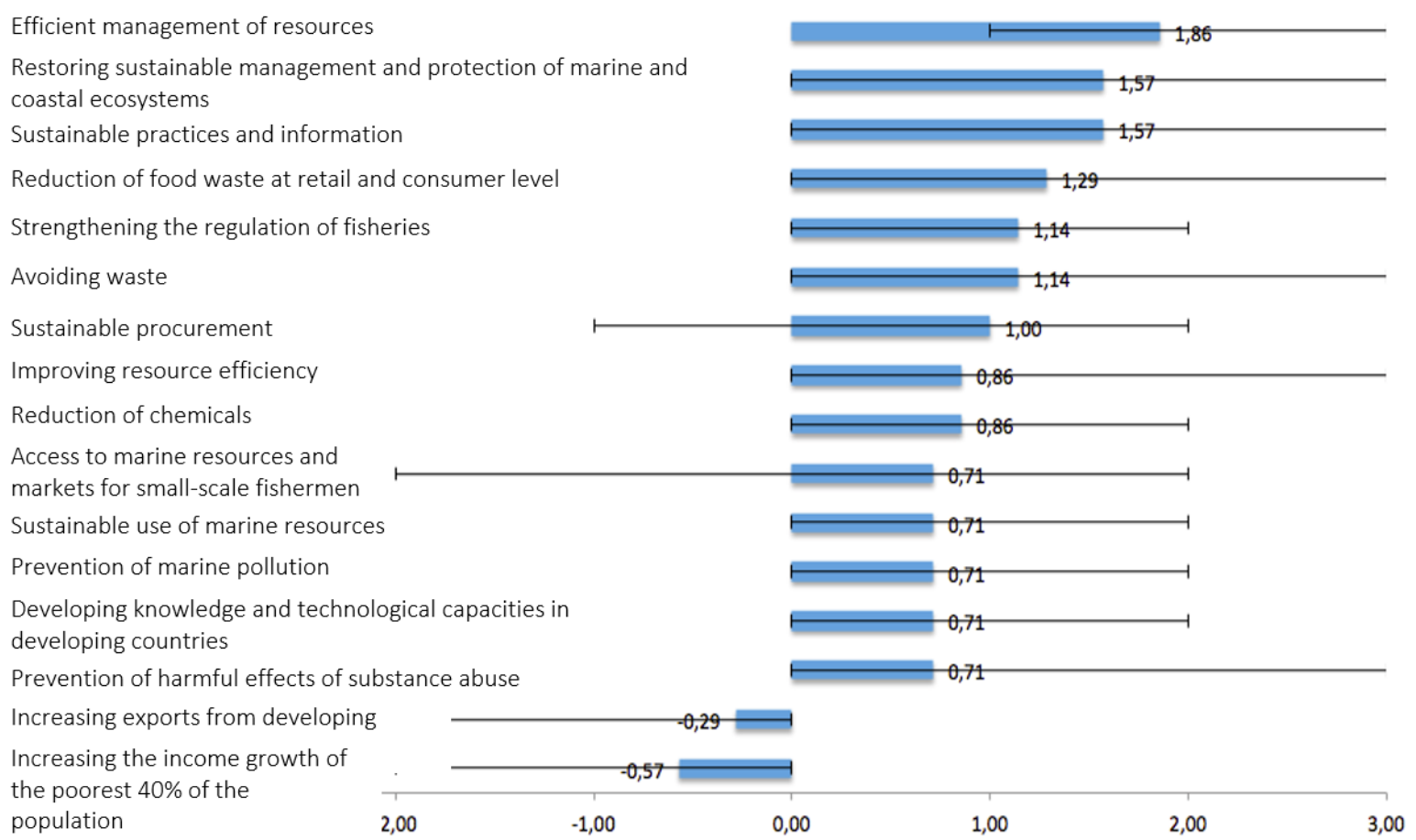

Figure 10. Results of the SDG-Check (Step 2) in the innovation project "Retail" (Source: translated from Kahl et al., 2017) 


\section{The SDG-Check: Guiding Open Innovation towards Sustainable Development Goals Justus von Geibler, Julius Piwowar, and Annika Greven}

\section{Evaluating the SDG-Check}

Based on the experience of the three innovation projects collected by workshop discussion and survey results, the overall finding points out that the application of the SDG-Check provides effective results and is very user-friendly. For example, the workshop discussion highlighted that the broad SDGs directed the innovation projects towards sustainability, without being too restrictive. Furthermore, the workshop discussions made clear that addressing the SDGs helps to cope with complexity and ambiguity because the SDGs have a very broad consensus and high legitimacy and thus built confidence and trust within the innovation process.

The survey results illustrate positive effectiveness and efficiency of the SDG-Check (Table 3). The findings indicate that the SDG-Check is a cost-efficient tool, which provides hints for ecological and social improvements. Finally, the SDG-Check is easy to use, not very time consuming (less than 20 minutes) and straightforward based on a simple and standard evaluation scheme (with a scale between 1 and 7 ).

\section{Implications}

\section{Implications for practitioners}

Based on the workshop discussion, the following implications for practitioners can be summarized:
- The SDG-Check enabled a harmonized communication about sustainability within the project team with sustainability and non-sustainability experts. It has been a platform for the development of a common understanding of sustainability and sustainability goals. Thereby, it supported decision-making in the teams based on semi-quantified results of the SDG-Check. As a consequence, the SDG-Check could inspire and encourage new business models and sustainability thinking in innovation processes.

- The SDG-Check is not very time consuming (less than 20 minutes) and is intuitively based on a simple and standard evaluation scheme with a seven-point scale. However, without an introduction and explanation, the SDGs can be abstract and unstructured and reduce the motivation to deal more closely with the SDG theme/sustainability and to take appropriate measures for product design into consideration.

- The complexity of the 17 goals and 169 targets could lead to a mental overload and demotivation, depending on the user's knowledge on the SDGs. However, the SDGs' communicative potential is very high because of their international recognition. They can be combined with other company-relevant methods (such as the SDG Compass; sdgcompass.org) and can serve as the basis for an enterprise-internal sustainability strategy. Additionally, the SDG-Check can support learning processes on the SDGs.

Table 3. Evaluation of the SDG-Check application (based on questionnaire survey with project leads) (Source: Geibler et al., 2018)

\begin{tabular}{|l|c|}
\hline Effectiveness & Score* $^{*}$ \\
\hline User integration & 0 \\
\hline User context integration & + \\
\hline Social aspects & 0 \\
\hline Ecological aspects & ++ \\
\hline
\end{tabular}

\begin{tabular}{|l|c|}
\hline Efficiency & Score* $^{*}$ \\
\hline Cost efficiency & ++ \\
\hline Technical efficiency & + \\
\hline Time efficiency & + \\
\hline Usability & ++ \\
\hline
\end{tabular}

*Legend: (--) very insufficient, (-) insufficient, (0) neutral, (+) good, (++) very good; the assessment is based on the mean value. 


\section{The SDG-Check: Guiding Open Innovation towards Sustainable Development Goals Justus von Geibler, Julius Piwowar, and Annika Greven}

\section{Implications for researchers}

Based on the workshop discussion, the following implications for academics can be summarized:

- The SDG-Check enables initial quantitative evaluation results at the very early innovation stage. This quantification can complement qualitative assessments, for example, to enable comparisons of different innovations (e.g., service models versus ownership models), different team members (e.g., designer vs. engineer), and different innovation phases (e.g., early phase vs. later phases).

- An in-depth sustainability analysis (e.g., environmental or social live circle assessment) could not be performed with the SDG-Check. For an effective sustainability analysis (e.g., with the hotspot analysis; Liedtke et al., 2013) this would be sensible: the selection of the goal and targets does not necessarily have to be the most significant sustainability potential of the innovation. The selection is based on a self-assessment, which can be used as a basis for the further dialogue and should be evaluated by other experts.

- In the context of innovation management, the application of the SDG-Check could be improved by embedding the tool into a holistic innovation and design culture, for example, one that is based on humancentred design and design-thinking approaches (e.g., Norman, 2013). This can allow for more effective combining of different tools and methods.

- Although the usability of the SDG-Check was evaluated positively, there are opportunities for improvements. For example, the findings encourage intuitive explorations of the SDGs and how they relate to an innovation project by providing more interactive qualities for innovators, for example, by involving gamification principles (e.g., Chou, 2016). Therefore, the tool could be delivered in a non-traditional setting aiming at an experiential and holistic learning approach, such as on drawing on the didactic approach of open-didactic exploration (Bliesner et al., 2014).

- To further support a common understanding of the fuzzy front end of innovation and its process, the tool could include extended questions focusing on the identification of the innovation readiness level as well as the degree of novelty (i.e., incremental vs. advanced or disruptive vs. radical).

\section{Conclusion}

The assessment of the early product and service design phases is of major importance since these early stages influence a high share of the cost spent for a product or service (i.e., production costs, maintenance costs, and end-of-life costs). Similarly, the environmental and social potential of an innovation are also determined in this front end of innovation development. Considering the complexity of technological implications on sustainability, it is necessary to assist innovators in developing and implementing technological innovations and the consideration of sustainability.

Two internationally known models - the TRL model by Mangans (1995) and Cooper's (1990) Stage-Gate model - have been combined in order to structure the open innovation process and guide sustainability assessments. This new model has been used to clearly define the fuzzy front end, where the identification and integration of sustainability aspects and stakeholder views is most important.

The presented SDG-Check is being developed in the research unit "Innovation labs" at the Wuppertal Institute to support the identification of the most relevant SDGs in the early stages of product and service innovation processes. Building on an online checklist and a participatory stepwise approach, the tool considers two different levels of detail: one at the level of 17 goals and another at the level of sub-goals. The digitalized processing of data enables the assessment of the large number of data entries and aggregations and comparisons of experts' views on the risk and opportunities of the innovation with regard to the SDGs. However, the single application of the assessment tool alone will not be sufficient to support sustainable innovations. Along with evaluations, it is necessary to develop a responsibly minded innovation culture that integrates sustainability as an inherent innovation objective. A corporate culture that promotes the "ability to learn" - the central point for our ability to innovate more sustainable production and consumption patterns.

Future research can be conducted based on a broader application of the SDG-Check in other cases. Hereby, the SDG-Check should be more extensively compared to other approaches focusing on innovation development at an early stage, such as Biomimicry 3.8 (Baumeister et al., 2013), the 10 Golden Rules (Luttropp 


\section{The SDG-Check: Guiding Open Innovation towards Sustainable Development Goals} Justus von Geibler, Julius Piwowar, and Annika Greven

\& Lagerstedt, 2006), the Need Cards (Hassenzahl et al., 2013), AttrakDiff 2 (UID, 2018), and Vision in Product Design (Dijk \& Hekkert, 2014). Also, pairing the SDGCheck with other tools, workshops, or services on a public platform like What Design Can Do (WDCD, 2018) or Ashoka Changemakers (Muskat \& Sylvester, 2012) should be considered further.

\section{Acknowledgements}

We are grateful to the INNOLAB team and practitioners offering their time and expertise in exploring the practical application of the SDG-Check.

An earlier version of this article was presented and discussed at Open Living Lab Days 2018, which was held in Geneva from August 22-24, 2018. We therefore thank the participants of the session on "Theoretical and Methodological Challenges" as well as the anonymous reviewers for their constructive feedback on the earlier versions of the article.

Finally, we acknowledge the funding received for the underlying research from the German Ministry of Research and Education for the INNOLAB project (Grant No. 01UT1418A).

\section{About the Authors}

Justus von Geibler co-leads the research unit Innovation Labs in the Division of Sustainable Production and Consumption at the Wuppertal Institute in Germany. Based on more than 20 years of professional experience in sustainable assessment and innovation, his research focuses on sustainability standards, sustainability innovations in value chains, open innovation in companies, and living labs. He coordinates the collaboration between the Wuppertal Institute and Climate-KIC. He holds a PhD in Economic Geography from the Ruhr University Bochum, Germany, a Master's in Forest Sciences from the University of Göttingen, Germany, and a Master's in Environmental Management and Policy from the University of Lund, Sweden. He has taught natural resource management, sustainability in global value chains, and sustainable supply chain management at Leuphana University Lüneburg, the University of Wuppertal, and the Said Business School at Oxford University, and he is the author of several books and over 100 scientific publications.

Julius Piwowar is a Research Fellow at the Wuppertal Institute in Germany with a double degree in Sustainability Management from the University of Oldenburg, Germany, and in Strategic Leadership towards Sustainability from the University of Karlskrona, Sweden. His research focuses on user experience design and living lab services.

Annika Greven studied industrial design engineering (BEng) at Fontys University of Applied Sciences in the Netherlands and strategic innovation in products and services (MA) at the University of Wuppertal, Germany. Her Master's thesis pointed out needs, potentials, and holistic design concepts in order to provide SMEs with a framework that methodologically helps them to develop a socially and ecologically sustainable business model. As a research fellow at the Wuppertal Institute, she is working with living lab services and sustainable business model design. Furthermore, she is working in a startup for sustainable fashion and as a freelancer in the field of design. Her research focuses on strategic innovation, product design, user-centred design, design thinking, business model design, and sustainability. 


\section{The SDG-Check: Guiding Open Innovation towards Sustainable Development Goals Justus von Geibler, Julius Piwowar, and Annika Greven}

\section{References}

Baumeister, D., Tocke, R., Dwyer, J., Ritter, S., \& Benyus, J. 2013. The Biomimicry Resource Handbook: A Seed Bank of Best Practices. Missoula, MT: Biomimicry 3.8.

Bonn, I., \& Fisher, J. 2011. Sustainability: The Missing Ingredient in Strategy. Journal of Business Strategy, 32(1): 5-14. https://doi.org/10.1108/02756661111100274

Broman, G. I., \& Robért, K.-H. 2017. A Framework for Strategic Sustainable Development. Journal of Cleaner Production, 140(1): 17-31.

https://doi.org/10.1016/j.jclepro.2015.10.121

Bliesner, A., Liedtke, C., Welfens, M., Baedeker, C., Hasselkuß, M., \& Rohn, H. 2014. Norm-Oriented Interpretation Learning" and Resource Use: The Concept of "Open-Didactic Exploration" as a Contribution to Raising Awareness of a Responsible Resource Use. MDPI Journal Resources, 3(1): 1-30.

https://doi.org/10.3390/resources3010001

Brezet, H., \& van Hemel, C. 1997. Ecodesign - A Promising Approach to Sustainable Production and Consumption. Paris: UNEP.

Buhl, J., Geibler, J. v., Echternacht, L., \& Linder, M. 2017. Rebound Effects in Living Labs: Opportunities for Monitoring and Mitigating Re-Spending and Time Use Effects in User Integrated Innovation Design. Journal of Cleaner Production, 151: 592-602. https://doi.org/10.1016/j.jclepro.2017.03.001

Charter, M., \& Tischner, U. 2001. Sustainable Solutions: Developing Products and Services for the Future. Sheffield, UK: Greenleaf.

Chesbrough, H. W. 2003. Open Innovation: The New Imperative for Creating and Profiting from Technology. Boston, MA: Harvard Business Review Press.

Chou, Y. K. 2016. Actionable Gamification: Beyond Points, Badges, and Leaderboards. Milpitas, CA: Octalysis Media.

Clausen, J., Fichter, K., \& Winter, W. 2011. Theoretische Grundlagen fü die Erklärung von Diffusionsverlaüfen von Nachhaltigkeitsinnovationen Grundlagenstudie. Verbundvorhaben im Rahmen der BMBF Bekanntmachung „Innovationspolitische Handlungsfelder für die nachhaltige Entwicklung" im Rahmen der Innovations- und Technikanalyse. Berlin: Borderstep Institut für Innovation und Nachhaltigkeit gemeinnützige $\mathrm{GmbH}$.

Cooper, R. G. 1990. Stage-Gate Systems: A New Tool for Managing New Products. Business Horizons, 33(3): 44-54.

Cooper, R. G. 2014. Invited Article: What's Next? After Stage-Gate. Research-Technology Management, 57(1): 20-31.

https://doi.org/10.5437/08956308X5606963

Dewulf, K. 2013. Sustainable Product Innovation: The Importance of the Front-End Stage in the Innovation Process. In D. Coelho (Ed.), Advances in Industrial Design Engineering: 139-166. London: IntechOpen.

http://doi.org/10.5772/52461

Diefenbach, S., \& Hassenzahl, M. 2017. Psychologie in der nutzerzentrierten Produktgestaltung. Mensch - Technik Interaktion - Erlebnis. Berlin, Heidelberg: Springer.

Diefenbach, S., Lenz, E., \& Hassenzahl, M. 2013. Experience Design Tools Ansätze zur Interaktionsgestaltung aus dem Blickwinkel psychologischer Bedürfnisse. UP14 - Tutorials. Stuttgart: German UPA.
Hekkert, P., \& van Dijk, M. 2014. Vision in Product Design - A Guidebook for Innovators. Amsterdam: BIS Publishers.

Diehl, B. 2011. Nachhaltigkeitsinnovationen im Bedarfsfeld Wohnen. In F. M. Belz, U. Schrader, \& M. Arnold (Eds.), NachhaltigkeitsInnovationen durch Nutzerintegration: 121-144. Weimar, Germany: Metropolis.

Echternacht, L., Geibler, J. v., Stadler, K., Behrend, J., \& Meurer, J. 2016. Methoden im Living Lab: Unterstützung der Nutzerintegration in offenen Innovationsprozessen (Entwurf Methodenhandbuch). Arbeitspapier im Arbeitspaket 2 (AS 2.2) des INNOLAB Projekts. Wuppertal, Germany: Wuppertal Institut für Klima, Umwelt, Energie.

Fichter, K., \& Clausen, J. 2016. Diffusion Dynamics of Sustainable Innovation - Insights on Diffusion Patterns Based on the Analysis of 100 Sustainable Product and Service Innovation. Journal of Innovation Management, 4(2): 30-67. https://doi.org/10.24840/2183-0606_004.002_0004

Fichter, K. 2005. Interpreneurship - Nachhaltigkeitsinnovationen in interaktiven Perspektiven eines vernetzenden Unternehmertums. Theorie der Unternehmung, 33. Weimar, Germany: Metropolis Verlag.

Geibler, J. v., Echternacht, L., Stadler, K., Liedtke, C., Hasselkuß, M., Wirges, M., Führer, J., Rösch, R., \& Piwowar, J. 2016. Nachhaltigkeitsanforderungen und -bewertung in Living Labs: Konzeption eines Bewertungsmodells. Arbeitspapier im Arbeitspaket 2 (AS 2.1) des INNOLAB Projekts. Wuppertal, Germany: Wuppertal Institut für Klima, Umwelt, Energie.

Geibler, J. v., Stadler, K., Piwowar, J., Greven, A., Schridde, S., Meurer, J., \& Zurkan, A. 2018. Living Lab-Methoden - Praxiserfahrungen aus dem INNOLAB-Projekt. Arbeitspapier im Arbeitspaket 6 des INNOLAB Projekts. Wuppertal, Germany: Wuppertal Institut für Klima, Umwelt, Energie.

Grönlund, J., Sjödin, D. R., \& Frishammar, J. 2010. Open Innovation and the Stage-Gate Process: A Revised Model for New Product Development. California Management Review, 52(3): 106-131. https://doi.org/10.1525/cmr.2010.52.3.106

Hansen, E. G., Grosse-Dunker, F., \& Reichwald, R. 2009. Sustainability Innovation Cube - A Framework to Evaluate SustainabilityOriented Innovations. International Journal of Innovation Management, 13(4): 683-713.

https://doi.org/10.1142/S1363919609002479

Hassenzahl, M., Eckoldt, K., Diefenbach, S., Laschke, M., Lenz, E., \& Kim, J. 2013. Designing Moments of Meaning and Pleasure. Experience Design and Happiness. International Journal of Design, 7(3): 21-31.

Herstatt, C., \& Verworn, B. 2001. The Fuzzy Front End of Innovation. Working Papers /Technologie-und Innovationsmanagement. Hamburg, Germany: Technische Universität Hamburg-Harburg. https://doi.org/10.15480/882.105

Howaldt, J., \& Schwarz, M. 2010. Soziale Innovationen im Fokus Skizze eines gesellschaftstheoretisch inspirierten Forschungskonzepts. Bielefeld, Germany: Transcript Verlag.

IISD 1997. Assessing Sustainable Development: Principles in Practice. (Bellagio Principles). Winnipeg, MB: International Institute for Sustainable Development (IISD).

INNOLAB. 2018. Living Labs in the Green Economy. INNOLAB. Accessed March 1, 2019: http://www.innolab-livinglabs.de/en.html 


\section{The SDG-Check: Guiding Open Innovation towards Sustainable Development Goals Justus von Geibler, Julius Piwowar, and Annika Greven}

Irwin, T. 2015. Transition Design: A Proposal for a New Area of Design, Practice, Study and Research. Design and Culture Journal, 7(2): 229-246.

https://doi.org/10.1080/17547075.2015.1051829

ISO 9241-210. 2010. Ergonomics of Human System Interaction-Part 210: Human-Centred Design for Interactive Systems. Geneva: International Standardization Organization (ISO).

Jacob, K., Graaf, L., \& Werland, S. 2016. Policy Paper 10: Handlungsbedarfe und Optionen für eine innovationsorientierte Ressourcenpolitik in planetaren Grenzen. Berlin: Free University of Berlin.

Jha, A., Kickbusch, I., Taylor, P., \& Abbasi, K. 2016. Accelerating Achievement of the Sustainable Development Goals. BMJ, 352: i409.

https://doi.org/10.1136/bmj.i409

Kahl, G., Herbig, N., Erdmann, L., Stadler, K., \& Peters, A. 2017. Ergebnisdokumentation des Praxisprojekts „Kundenführung am Point of Sale". Arbeitspapier im Arbeitspaket 4 (AP 4.4) des INNOLAB Projekts. Saarbrücken, Germany: Deutsches Forschungszentrum für Künstliche Intelligenz (DFKI GmbH).

Kim, J., \& Wilemon, D. 2002. Focusing the Fuzzy Front-End in New Product Development. R\&D Management, 32(4): 269-279.

https://doi.org/10.1111/1467-9310.00259

Krein, J., Faller, A., Zurkan, A., Geibler, J. v., \& Stadler, K. 2017. Praxisund Meilensteinbericht zum Arbeitspaket 3. Arbeitspapier im Arbeitspaket 3 (AS 3.4) des INNOLAB Projekts. Duisburg, Germany: Fraunhofer-Institut für Mikroelektronische Schaltungen und Systeme IMS.

Kuijer, L., \& de Jong, A. M. 2011. Practice Theory and Human-Centered Design: A Sustainable Bathing Example. Paper presented at the 2011 Nordic Design Research Conference, Helsinki, Finland.

Leimeister, J. M. 2010. Kollektive Intelligenz. Wirtschaftsinformatik, 52(4): 239-242.

https://doi.org/10.1007/s12599-010-0114-8

Liedtke, C., Welfens, M. J., Rohn, H., \& Nordmann, J. 2012. LIVING LAB: User-Driven Innovation for Sustainability. International Journal of Sustainability in Higher Education, 13(2): 106-118. https://doi.org/10.1108/14676371211211809

Liedtke, C., Baedecker, C., Hasselkuß, M., Rohn, H., \& Grinewitschus, V. 2015. User-Integrated Innovation in Sustainable LivingLabs: An Experimental Infrastructure for Researching and Developing Sustainable Product Service Systems. Journal of Cleaner Production, 97: 106-116.

https://doi.org/10.1016/j.jclepro.2014.04.070

Liedtke, C., Ameli, N., Buhl, J., Oettershagen, P., Pears, T., \& Abbis, P. 2013. Design Guide: Backgound Information and Tools. Wuppertal, Germany: Wuppertal Insitute.

Lozano, R. 2015. A Holistic Perspective on Corporate Sustainability Drivers. Corporate Social Responsibility and Environmental Management, 22(1): 32-44. https://doi.org/10.1002/csr.1325

Luttropp, C., \& Lagerstedt, J. 2006. EcoDesign and The Ten Golden Rules: Generic Advice for Merging Environmental Aspects into Product Development. Journal of Cleaner Production, 14(15-16): 1396-1408.

https://doi.org/10.1016/j.jclepro.2005.11.022
Meurer, J., Geibler, J. v., Stadler, K., Koch, H., \& Rudigier, G. 2017. Gestaltung einer intermodalen und ressourcenschonenden Mobilitäts-App im Alter mit dem Living Lab Ansatz. Arbeitspapier im Arbeitspaket 5 (AS 5.4) des INNOLAB Projekts. Siegen, Germany: Universität Siegen.

Muskat, E., \& Sylvester, D. 2012. Being Disruptive: How Open Growth is Delivering Effective Social Change at a Fast Pace. Technology Innovation Management Review, 2(7): 16-20.

http://doi.org/10.22215/timreview/576

Nakamura, H., Kajikawa, Y., \& Suzuki, S. 2013. Multi-level Perspectives with Technology Readiness Measures for Aviation Innovation. Sustainability Science, 8(1): 87-101. https://doi.org/10.1007/s11625-012-0187-z

Norman, D. 2013. The Design of Everyday Things. New York: Basic Books.

Norman, D., \& Verganti, R. 2014. Incremental and Radical Innovation: Design Research vs. Technology and Meaning Change. Design Issues, 30(1): 78-96. https://doi.org/10.1162/DESI_a_00250

Oksanen, K., \& Hautamäki, A. 2015. Sustainable Innovation: A Competitive Advantage for Innovation Ecosystems. Technology Innovation Management Review, 5(10): 24-30. http://doi.org/10.22215/timreview/934

Paech, N. 2005. Nachhaltigkeit als marktliche und kulturelle Herausforderung. In Fichter, K., Paech, N., Pfriem, R. (Eds.), Nachhaltige Zukunftsmärkte: 51-88. Weimar, Germany: Metropolis.

Phillips, P. L. 2004. Creating the Perfect Design Brief: How to Manage Design for Strategic Advantage. New York: Allworth.

Robèrt, K.-H., Broman, G., \& Basile, G., 2013. Analyzing the Concept of Planetary Boundaries from a Strategic Sustainability Perspective: How Does Humanity Avoid Tipping the Planet? Ecology and Society, 18(2): 5. http://dx.doi.org/10.5751/ES-05336-180205

Rockström, J., Steffen, W., Noone, K., Persson, A., \& Chapin, F. S. 2009. A Safe Operating Space for Humanity. Nature, 461: 472-475. http://dx.doi.org/10.1038/461472a

Salzmann, O., Ionescu-Somers, A., \& Steger, U. 2005. The Business Case for Corporate Sustainability: Literature Review and Research Options. European Management Journal, 23(1): 27-36. https://doi.org/10.1016/j.emj.2004.12.007

Sandner, P. G., \& Block, J. 2011. The Market Value of R\&D, Patents, and Trademarks. Research Policy, 40(7): 969-985. http://dx.doi.org/10.1016/j.respol.2011.04.004

Schmidt-Bleek, F., \& Tischner, U. 1995. Produktentwicklung, Nutzen gestalten - Natur schonen. WIFI Broschüre No 270. Vienna: Wirtschaftskammer Österreich.

Smith, K. H. 2006. Measuring Innovation. In J. Fagerberg, D. C. Mowery, \& R. R. Nelson (Eds.), The Oxford Handbook of Innovation: 148-179. Oxford: Oxford University Press.

Sommer, B., \& Welzer, H. 2014. Transformationsdesign. Wege in eine zukunftsfähige Moderne. Munich: Oekom Verlag.

Søndergaard, H. A., \& Burcharth, A. L. 2011. Open Innovation Practices and Implementation Barriers: Unwillingness to Receive and Share Knowledge. Paper presented at the 2011 DRUID Conference, Copenhagen. 


\section{The SDG-Check: Guiding Open Innovation towards Sustainable Development Goals Justus von Geibler, Julius Piwowar, and Annika Greven}

Steffen, W., Richardson, K., Rockström, J., Cornell, S. E., Fetzer, I., Bennett, E. M., Biggs, R., Carpeter, S. R., de Vries, W., de Wit, C. A., Folke, C., Gerten, D., Heinke, J., Mace, G. M., Persson, L. M., Ramanathan, V., Reyers, B., \& Sörlin, S. 2015. Planetary Boundaries: Guiding Human Development on a Changing Planet. Science, 347(6223).

http://dx.doi.org/10.1126/science.1259855

Storaker, A., Wever, R., Dewulf, K., \& Blankenburg, D. 2013. Sustainability in Front-End Innovation at Design Agencies. In Proceedings of the 8th International Symposium on Environmentally Conscious Design and Inverse Manufacturing, Jeju Island, Korea, December 4-8, 2013.

Surowiecki, J. 2004. The Wisdom of Crowds: Why the Many Are Smarter Than the Few and How Collective Wisdom Shapes Business, Economies, Societies and Nations. London: Little Brown.

Tischner, U. 2015. Was ist EcoDesign?: Ein Handbuch für ökologische und ökonomische Gestaltung. Frankfurt: Verlag form Praxis.

Talwar, S., Wiek, A., \& Robinson, J. 2011. User Engagement in Sustainability Research. Science and Public Policy, 38(5): 379-390. https://doi.org/10.3152/030234211X12960315267615

Tierney, R., Hermina, W., \& Walsh, S. 2013. The Pharmaceutical Technology Landscape: A New Form of Technology Roadmapping. Technological Forecasting and Social Change, 80(2): 194-211. https://doi.org/10.1016/j.techfore.2012.05.002
Ullman, D. G. 1997. The Mechanical Design Process. (2nd ed.) New York: McGraw-Hill.

UN. 2015. Resolution: Transforming our World: The 2030 Agenda for Sustainable Development. New York: United Nations (UN).

Val-Jauregi, E., \& Justel, D. 2007. Use of Tools, Methods and Techniques During the Fuzzy Front End of Innovation: Their Impact on Innovation Performance - A Survey Based Exploratory Study of Companies in the Basque Country. Paper presented at the 2017 International Conference on Engineering Design (ICED).

Verworn, B. A. 2009. Structural Equation Model of the Impact of the "Fuzzy Front End" on the Success of New Product Development. Research Policy, 38(10): 1571-1581. https://doi.org/10.1016/j.respol.2009.09.006

von Hippel, E. 2001. Wettbewerbsfactor Zeit. Moderne Industrie; 1993. In The Fuzzy Front End of Innovation, Working paper by Herstatt C. and Verworn, B.

von Hippel, E. 1986. Lead Users: A Source of Novel Product Concepts. Management Science, 32(7): 791-805. https://doi.org/10.1287/mnsc.32.7.791

WDCD. 2018. Design Challenges. WDCD (What Design Can Do). Accessed March 1, 2019:

http://www.whatdesigncando.com/challenge/ 


\section{Academic Affiliations and Funding Acknowledgements}
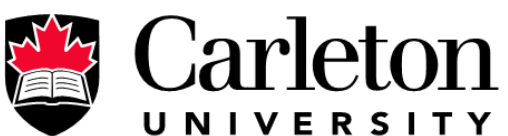

U N I V E R S I T Y

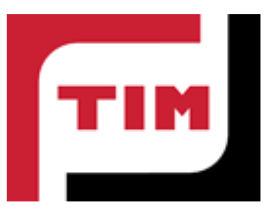

Technology Innovation Management (TIM; timprogram.ca) is an international master's level program at Carleton University in Ottawa, Canada. It leads to a Master of Applied Science (M.A.Sc.) degree, a Master of Engineering (M.Eng.) degree, or a Master of Entrepreneurship (M.Ent.) degree. The objective of this program is to train aspiring entrepreneurs on creating wealth at the early stages of company or opportunity lifecycles.

- The TIM Review is published in association with and receives partial funding from the TIM program. 